\section{A REVOLUÇÃO DA ESCRITA NA GRÉCIA E SUAS CONSEQÜÊNCIAS CULTURAIS}

\section{HAVELOCK, Eric A.}

São Paulo: Editora da UNESP/ Paz e Terra, 1996. $370 \mathrm{p}$.

A história desse livro começa há cerca de trinta anos, data de publicação de dois dos ensaios nele reunidos. Os outros foram escritos ao longo da década de setenta $e$ divulgados em revistas acadêmicas. Enganase, no entanto, quem imagina que as teses ali apresentadas perderam a força com o passar dos anos ou que interessam apenas aos helenistas. As idéias de Eric Havelock mantêm-se atuais e instigantes e ultrapassam a fronteira dos estudos clássicos, chamando a atenção de educadores, antropólogos, historiadores e filósofos.

Havelock dedicou-se ao estudo da comunicação na Grécia antiga, interessandose especialmente pelos efeitos da introdução de uma nova mídia, a escrita alfabética, sobre a organização e expressão do pensamento. A premissa é que todo avanço tecnológico determina uma mudança no campo das mentalidades. Ou seja, a forma influencia o conteúdo, tema atualíssimo quando se discute, por exemplo, as conseqüências da Internet sobre a linguagem.

Primeiro, os gregos desenvolveram uma escrita de caráter silabar (baseada na sílabas), conhecida por linear $b$, que, por estar restrita ao uso de escribas palacianos, desapareceu no séc. XIII a.C. após um turbulento período de revoluções, invasões e catástrofes naturais. Cerca de quatro séculos depois, o empréstimo $e$ a adaptação da escrita fenícia permitiram a invenção do alfabeto.

A novidade grega consistiu em atribuir sinais para designar as vogais, que deveriam combinar-se com outros, que indicavam as consoantes. Parece pouco, mas significou muito. A notação de fonemas permitiu uma economia enorme de signos, principalmente em comparação com as escritas silabares $e$ ideogramáticas. A grande quantidade de letras dessas escritas dificultava bastante sua difusão para amplas parcelas da população, tornando-as limitadas a uma classe de peritos (veja-se o caso do linear). Por outro lado, a marcação das vogais facilitou o ato de ler ao eliminar a ambigüidade de uma escrita puramente consonantal, em que, por exemplo, o termo "bl” poderia ser lido como bala, bola, bula, etc.

Essas duas razões, economia de sinais e eliminação da ambigüidade, explicariam o sucesso do alfabeto grego, que está na origem do latino e do cirílico, utilizados largamente hoje em dia. Havelock, numa tirada etnocentrista, chega a considerá-lo a escrita ideal, superior a todas as demais. Embora deva-se concordar com essa avaliação no que concerne às línguas indo-européias, é bom ressalvar que o mesmo raciocínio não se aplica necessariamente às demais famílias lingüisticas.

A invenção do alfabeto na Grécia não significou, entretanto, a disseminação instantânea das artes da escrita e da leitura. 
Ao contrário, o domínio da nova técnica demandou séculos de prática para firmar-se, ao longo dos quais o registro escrito, limitado a poucos especialistas, conviveu com o oral. Por isso, por paradoxal que possa parecer, Eric Havelock é também um dos grandes estudiosos da oralidade na antigüidade clássica, juntamente com Parry no começo deste século.

Sua contribuição foi pensar a poesia como a principal forma de expressão na Grécia pré e pós-letrada, capaz não só de divertir, mas também de transmitir conhecimento. Ao organizar a matéria a ser tratada em imagens e sons recorrentes, ela favorecia a sua memorização. A epopéia homérica, chamada por Havelock de "enciclopédia da tribo", tem papel de destaque nesse processo ao reunir um grande conjunto de informações de cunho ético e técnico sem ser abertamente didática. Em menor grau, o mesmo vale para a lírica arcaica e para o drama ático. Esse estado de coisas persistiu pelo menos até o fim do séc. $V$ a.C., quando a alfabetização da população urbana já existia em uma escala considerável, proporcionando condições favoráveis para novas experiências.

Para Havelock, não foi obra do acaso que a filosofia tenha surgido na Grécia, mas decorrência direta da introdução do alfabeto. $O$ registro escrito libera a energia, antes gasta com a memorização, para novas descobertas, favorecendo o acúmulo do saber e a criação do pensamento conceitual. Nesse cenário se dá o nascimento da prosa, que aparece como o veículo adequado a expressar as ciências emergentes: medicina, historiografia, geografia, além das reflexões de Platão e Aristételes.

Como seria de se esperar, esse momento de grande transformação cultural é também de confronto, já que as novas ciências contestam a autoridade da poesia, que passa a ser considerada apenas uma forma de entretenimento. A crítica da filosofia à poesia também foi objeto da atenção de Havelock, mas em outro livro, Prefácio a Platão, traduzido recentemente para o português.

Havelock é um pensador brilhante e original, mas tem um pecado: o gosto pela polêmica. É evidente seu prazer em defender, mesmo contra todas as evidências, teses no mínimo suspeitas como uma data recente para a invenção do alfabeto grego ou sua superioridade sobre as escritas pictográficas orientais. Porém não se pode negar que esse traço contribui para tornar atraente sua leitura. Com certeza, A Revolução da escrita na Grécia e suas conseqüências culturais é uma ótima introdução a sua obra e também à problemática da oralidade e da escrita tanto na Grécia antiga quanto nos dias de hoje.

Adriane da Silva Duarte Professora Assistente de Língua e Literatura Grega FFLCH, USP 